(2) Open Access Full Text Article

\title{
Comment on:"Three-year follow-up of ranibizumab treatment of wet age-related macular degeneration: influence of baseline visual acuity and injection frequency on visual outcomes"
}

\author{
This article was published in the following Dove Press journal: \\ Clinical Ophthalmology \\ 18 April 2016 \\ Number of times this article has been viewed
}

\author{
Abdullah Kaya \\ Department of Ophthalmology, \\ Anıttepe Military Dispensary, \\ Ankara, Turkey
}

\section{Dear editor}

I read the current article titled "Three-year follow-up of ranibizumab treatment of wet age-related macular degeneration: influence of baseline visual acuity and injection frequency on visual outcomes" by Razi et al, ${ }^{1}$ with great interest. Authors present outcomes of ranibizumab treatment of wet age related macular degeneration. I congratulate authors for this well organized study.

Major disadvantage of treatment with anti-VEGF drugs is the recurrence of wet age related macular degeneration. Monthly or bimonthly injection is needed in lots of patients. Changes in visual acuity (VA) at 1,2 and 3 year were evaluated in this study. Considering recurrence, time between last injection and VA measurement is important. Pro re nata (PRN) treatment regimen was applied to patients in this study. This means that some patients could be treated 1 month before measurement at 1,2 or 3 years and some patients could be treated more than 1 month before the measurement. Elongation of time interval may increase risk of recurrence and cause a lower measurement of VA. Thus, it would be better to include VA measurements that are taken 1 month after closest treatments to each year. VA was found to be positively correlated with injection frequency. Increase of injection frequency also increases possibility of last treatments of each year to be closer to the measurement.

\section{Disclosure}

The author reports no conflicts of interest in this communication.

\section{Reference}

1. Razi F, Haq A, Tonne P, Logendran M. Three-year follow-up of ranibizumab treatment of wet age-related macular degeneration: influence of baseline visual acuity and injection frequency on visual outcomes. Clin Ophthalmol. 2016;10:313-319.
Correspondence: Abdullah Kaya Department of Ophthalmology, Anıttepe Military Dispensary, Yucetepe Mah, Gençlik Cad 88, Sok Çankaya, Ankara 06280, Turkey

Tel +905301409305

Email abdullahkayamd@gmail.com

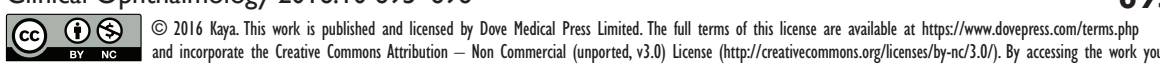
hereby accept the Terms. Non-commercial uses of the work are permitted without any further permission from Dove Medical Press Limited, provided the work is properly attributed. For permission for commercial use of this work, please see paragraphs 4.2 and 5 of our Terms (https://www.dovepress.com/terms.php). 
Dove Medical Press encourages responsible, free and frank academic debate. The content of the Clinical Ophthalmology 'letters to the editor' section does not necessarily represent the views of Dove Medical Press, its officers, agents, employees, related entities or the Clinical Ophthalmology editors. While all reasonable steps have been taken to confirm the content of each letter, Dove Medical Press accepts no liability in respect of the content of any letter, nor is it responsible for the content and accuracy of any letter to the editor.

\section{Publish your work in this journal}

Clinical Ophthalmology is an international, peer-reviewed journal covering all subspecialties within ophthalmology. Key topics include: Optometry; Visual science; Pharmacology and drug therapy in eye diseases; Basic Sciences; Primary and Secondary eye care; Patient Safety and Quality of Care Improvements. This journal is indexed on
PubMed Central and CAS, and is the official journal of The Society of Clinical Ophthalmology (SCO). The manuscript management system is completely online and includes a very quick and fair peer-review system, which is all easy to use. Visit http://www.dovepress.com/ testimonials.php to read real quotes from published authors. 